Article

\title{
Forage Yield and Nutritive Value of Cool-Season and Warm-Season Forages for Grazing Organic Dairy Cattle
}

\author{
Kathryn E. Ritz ${ }^{1}$, Bradley J. Heins ${ }^{1, * \mathbb{C}}$, Roger Moon ${ }^{2}$, Craig Sheaffer ${ }^{3}$ and Sharon L. Weyers ${ }^{4}$ \\ 1 West Central Research and Outreach Center, University of Minnesota, 46352 MN-329, Morris, \\ MN 56267, USA; ruhxx011@umn.edu \\ 2 Department of Entomology, University of Minnesota, St. Paul, MN 55108, USA; rdmoon@umn.edu \\ 3 Department of Agronomy and Plant Genetics, University of Minnesota, St. Paul, MN 55108, USA; \\ sheaf001@umn.edu \\ 4 USDA North Central Soil Conservation Research Lab., Morris, MN 56267, USA; sharon.weyers@usda.gov \\ * Correspondence: hein0106@umn.edu
}

Received: 13 November 2020; Accepted: 10 December 2020; Published: 14 December 2020

check for updates

\begin{abstract}
The objective of this study was to compare the forage nutritive value of cool-season perennial grasses and legumes with that of warm-season annual grasses grazed by organic dairy cows. Two pasture systems were analyzed across the grazing season at an organic dairy in Morris, Minnesota. Pasture system 1 included perennial ryegrass (Lolium perenne L.), orchardgrass (Dactylis glomerata L.), meadow bromegrass (Bromus riparius Rehmann), meadow fescue (Schedonorus pratensis (Huds.) P. Beauv), alfalfa (Medicago sativa L.), white clover (Trifolium repens L.), red clover (Trifolium pratense L.), and chicory (Cichorium intybus L.). Pasture system 2 was a combination of system 1 and monocultures of warm-season grasses (sorghum-sudangrass (Sorghum bicolor [L.] Moench subsp. drummondii [Steud.]) and teff (Eragrostis tef L.)). Across the grazing season, forage yield was 39\% greater for system 2 than system 1 due to greater forage yield during the summer. Neutral detergent fiber (NDF) and acid detergent fiber (ADF) were similar for cool-season and warm-season grasses. Warm-season grasses had greater forage yield during the summer months compared with cool-season grasses and legumes. The total tract NDF digestibility (TTNDFD) varied by month and year across the study for both pasture systems. Overall, weather may affect the forage nutritive value for both cool-season perennial grasses and legumes and warm-season annual grasses.
\end{abstract}

Keywords: grazing; teff; forages; cattle; sorghum-sudangrass

\section{Introduction}

Pasture-based dairy production may be an economically competitive management system, with benefits that include less labor, lower investments of facilities, and comparable net income to confinement dairy systems [1]. The profitability of grazing dairy farms is determined by pastures that produce a large quantity of high nutritive value forage for cattle to graze throughout the grazing season. Dry matter intake (DMI), and ultimately milk production, is controlled by forage biomass [2]. Organic dairy cattle in the USA require at least $120 \mathrm{~d}$ of grazing, with $30 \%$ of their daily dry matter intake from pasture according to the USDA National Organic Pasture guidelines [3].

Managing short seasonal pastures for grazing is a skill shared by all cattle producers in the Upper Midwest of the USA due to long and cold winters. However, grazing represents a low-cost strategy for feeding dairy cattle during the summer. Cool-season perennial (CSP) grasses are the foundation of dairy pastures, which are typically productive between May and September in the northern half 
of the USA. However, increasing seasonal grazing duration of perennial pastures may exist via the utilization of alternative forages.

For the Upper Midwest, USA, cool-season grasses and legumes are the traditional pasture forages grown by many grazing dairy producers. However, CSP pasture species experience a decreased growth rate, or "summer slump," during periods of high temperatures and low precipitation, commonly observed in July and August in the Upper Midwest [4,5]. Warm-season annual (WSA) grasses have been proposed to augment CSP species yield during the summer slump [6]. The WSA grasses incorporated into a grazing system may provide an opportunity to rest CSP grasses when growth conditions are limited, as well as increased flexibility of the grazing system [4].

Farmers may be reluctant to incorporate WSA grasses into a grazing system because of concerns about potentially reduced forage nutritive value of these grasses. Previous research in the Midwest, USA, indicated that warm-season grasses had lower crude protein $(\mathrm{CP})$ and higher neutral detergent fiber (NDF) than CSP species [4,5,7], but they are seldom evaluated under cattle grazing conditions. Forage nutritive value is an important component for the formulation of the dairy cattle diet [8], and therefore, grazing producers may include WSA grasses in grazing systems.

Grazing producers in the Upper Midwest and Northeast, USA, have incorporated forage sorghum (Sorghum bicolor (L.) Moench subsp. bicolor), sudangrass (Sorghum bicolor (L.) Moench subsp. drummondii (Steud.) de Wet ex Davidse), and hybrids of sorghum and sudangrass into grazing systems $[1,9,10]$. Sorghum and sudangrass and hybrids of sorghum and sudangrass are desired for their persistent yield during mid- to late summer when CSP grasses may become dormant [11]. In an Illinois beef cow-calf grazing system, forage yield for brown-midrib sorghum $\times$ sudangrass (BMRSS) was greater than that for CSP grasses in July and August [7]. Furthermore, teff (Eragrostis tef) has been proposed for Midwest dairy grazing systems for use during drought periods; however, very few producers utilize teff in grazing pastures. Teff is fast growing and leafy but had lower yield potential than sorghum or sudangrass $[6,11]$, but little is known about its forage nutritive value under dairy cattle grazing and how dairy cattle may perform on teff. However, no research has compared BMRSS and teff by grazing dairy cattle. Grazing dairy producers have started to utilize warm-season grasses in the Midwest, USA, and grow warm-season grasses in monoculture. The current study mimicked current producer conditions to be able to provide valuable information for grazing dairy producers. Warm-season grasses have higher fiber concentration and lower nutritional values compared with cool-season grasses, and these grasses may have the ability to meet or exceed nutrient requirements for dairy cattle. Furthermore, the utility of adding teff in a rotational pasture system has not been established in northern regions. Therefore, it is necessary to investigate forages that are intended for grazing in realistic large-scale grazing systems. The hypothesis of the study was that warm-season annual grasses would have similar forage nutritive value to CSP grasses for use in dairy grazing systems. The objective of this study was to compare pasture forage yield and nutritive value and mineral content of CSP grasses, BMRSS, and teff for grazing systems for organic dairy grazing systems in the Upper Midwest.

\section{Materials and Methods}

\subsection{Site Description and Pasture Establishment}

The certified organic dairy research facility at the University of Minnesota West Central Research and Outreach Center in Morris, Minnesota $\left(45.59^{\circ} \mathrm{N}, 95.91^{\circ} \mathrm{W}\right)$, has a rotational grazing system with 150 lactating cows. The soil was a mixture of loamy Hokans-Buse and Barnes-Buse soils with average $\mathrm{pH}, \mathrm{N}, \mathrm{P}$, and $\mathrm{K}$ of $7.25,13 \mathrm{mg} \mathrm{kg}^{-1}, 16 \mathrm{mg} \mathrm{kg}^{-1}$, and $285 \mathrm{mg} \mathrm{kg}^{-1}$, respectively, and soil samples were taken from $0-15 \mathrm{~cm}$ depths. All aspects of the organic production system, regulated by the United States Department of Agriculture National Organic Program, are fully certified. Pastures were not fertilized. Nutrient cycling occurred only through nutrient pools common to grazed pastures, including plant litter and deposition of urine and dung by grazing cattle [12]. 
Two grazing management systems were compared. System 1 was season-long rotational grazing of a diverse mixture of CSP grasses and legumes (perennial ryegrass (Lolium perenne L.), orchardgrass (Dactylis glomerata L.), meadow bromegrass (Bromus riparius Rehmann), meadow fescue (Schedonorus pratensis [Huds.] P. Beauv.), alfalfa (Medicago sativa L.), white clover (Trifolium repens L.), red clover (Trifolium pratense L.), and chicory (Cichorium intybus L.)). The CSP grasses and legumes were established with a no-till drill into existing pastures in early April 2012. Pure live seeding rates for system 1 were $4.5 \mathrm{~kg} / \mathrm{ha}$ for perennial ryegrass, $3.4 \mathrm{~kg} / \mathrm{ha}$ for orchardgrass, $2.3 \mathrm{~kg} / \mathrm{ha}$ for meadow bromegrass, $9 \mathrm{~kg} / \mathrm{ha}$ for meadow fescue, $4.5 \mathrm{~kg} / \mathrm{ha}$ for alfalfa, $4.5 \mathrm{~kg} / \mathrm{ha}$ for white clover, $3.4 \mathrm{~kg} / \mathrm{ha}$ for red clover, and $1.2 \mathrm{~kg} / \mathrm{ha}$ for chicory. The cool-season grass and legume pastures were not fertilized, and no manure was applied. System 2 included CSP grasses grazed in spring and fall with WSA grasses (BMRSS and teff) grazed during the summer months. BMRSS and teff were planted into separate monoculture pastures. A total of 46.4 ha of pasture was used in this study. System 1 had a total of 17.4 ha of CSP pastures across five individual pastures, and system 2 had a total of 11.9 ha of CSP pastures across four individual pastures and a total of 17.1 ha of WSA pastures across three individual pastures. This study was conducted across 12 different pastures that were subdivided into replicated paddocks for cattle grazing. Each pasture was divided into approximately eight 0.60 ha paddocks in order to implement rotational stocking methods. Paddocks were replicated three times across the individual pasture systems.

Throughout the study, experimental units were grazed rotationally in recurring periods of grazing and rest among the paddocks within the pastures. This design followed procedures outlined by Fisher [13] for grazing trials, which include animal groups on pasture units. The rotation cycles were the same for all grazing cattle. The paddocks remained in the same configuration for each grazing period. Grazing of CSP grasses was initiated when the sward height reached 20 to $30 \mathrm{~cm}$, and stocking days were adjusted to leave 7 to $13 \mathrm{~cm}$ of stubble heights. The botanical composition of the CSP pastures was $70 \%$ grasses and $30 \%$ legumes.

Warm-season annual grasses were planted into prepared seedbeds in late May 2013, 2014, and 2015. The WSA grasses were planted into pastures that were previously composed of quackgrass (Elymus repens (L) Gold.), Kentucky bluegrass (Poa pratensis L.), and smooth brome (Bromus inermis Leyss. subsp. inermis). BMRSS (Black Hawk 12 Organic, Blue River Hybrids, Ames, IA, USA) and teff (Moxie, Albert Lea Seedhouse, Albert Lea, MN, USA) were seeded at $22 \mathrm{~kg} / \mathrm{ha}$ and $9 \mathrm{~kg} / \mathrm{ha}$, respectively. Both WSA species were planted 2.54 to $3.8 \mathrm{~cm}$ deep when soil temperatures reached 16 to $18^{\circ} \mathrm{C}$. BMRSS was allowed to grow at least $45 \mathrm{~cm}$ before grazing to minimize the risk of prussic acid poisoning. Teff was grazed in a manner similar to the CSP species and grazed at 20 to $30 \mathrm{~cm}$ with 7 to $13 \mathrm{~cm}$ of stubble. The rest time for each paddock varied from 21 to $35 \mathrm{~d}$. The warm-season grass pastures were not fertilized.

\subsection{Cattle Grazing of Pastures}

Ninety lactating Holstein and crossbred certified organic cows grazed forages of the two pasture systems (three replicates per system and six groups of 15 cows each on pasture) over three summer grazing seasons (28 May 2013 to 20 September 2013; 2 June 2014 to 22 October 2014; 18 May 2015 to 17 October 2015). The cows were Holstein and crossbreds composed of Holstein, Jersey, Normande, Viking Red, and Montbéliarde. They were balanced within the three replicates by breed, DIM, and parity and randomly assigned to systems 1 or 2 . All groups were provided with free choice mineral ad libitum and $2.3 \mathrm{~kg} / \mathrm{cow} /$ day ground corn to manage milk urea nitrogen levels.

The cows grazed for $22 \mathrm{~h}$ per day, except for the $2 \mathrm{~h}$ when they were milked twice per day. They were moved to a new paddock within a specific pasture every two days when the target stubble height was reached. The cows in system 1 always moved to a new paddock within a specific pasture of CSP grasses and grazed from May to October. For system 2, the decision to move the cows was based on the availability of the WSA grasses, so the cows were moved either to a new CSP paddock or to a WSA paddock if BMRSS or teff was ready to be grazed. All the procedures involving animal care and management were approved by the University of Minnesota Institutional Animal Care and Use Committee (\#1508-32966A). 


\subsection{Forage Sampling and Analysis}

Forage samples from paddocks were collected before cows moved into a new CSP or WSA paddock from a specific pasture. Three random unbiased samples were collected from within each paddock by throwing a $0.23 \mathrm{~m}^{2}$ square quadrant across the entire pasture and clipping the forage within the square to the established stubble height. These samples represented the forage available for cattle consumption. Residue from the paddock that the cows were moved from was also collected with the same method as in pregrazing samples. Therefore, during a forage collection, 18 pregrazing and 18 postgrazing samples were collected. The 18 clipped samples were dried at $60^{\circ} \mathrm{C}$ for $48 \mathrm{~h}$ to determine the dry matter (DM) concentration, and the average forage DM yield was extrapolated to a total of the forage samples from the sampled paddocks. Estimated DM values were summed across the grazing season to determine total forage mass (kg DM/ha). Forage mass was determined only for 2014 and 2015.

One of the three random samples collected from each paddock was analyzed for forage nutritive value. Dried samples were ground with a two mm screen (Model 4, Wiley Mill, Thomas Scientific, Swedesboro, NJ, USA) and stored in plastic vials prior to shipment for analysis. The samples were ground to $1 \mathrm{~mm}$ before analysis of the forage nutritive value by near infrared reflectance spectroscopy (NIR), which used standard equations at Rock River Laboratory, Inc. (Watertown, WI, USA). The instrument used for NIR was the FOSS/NIR Systems model 5000 (FOSS North America, Eden Prairie, MN, USA), which generates spectral data in the range of 1100-2498 nm on a $2 \mathrm{~nm}$ increment. Calibrations were developed using the modified partial least squares regression method from within the WinISI version 4 software package from Foss. The NIR calibrations were built against wet chemistry analysis at Rock River Laboratory, Inc. Rock River Laboratory has developed NIR calibrations for mixed grass pasture and forage sorghum. The CP, NDF, and acid detergent fiber (ADF) were analyzed by NIR. Mineral composition was determined with wet chemistry with an inductively coupled plasma model (AOAC Official Method 2015.01). The total tract NDF digestibility (TTNDFD) was measured with validated in vitro procedures [14,15]. A total of 280 CSP, 69 BMRSS, and 26 teff samples were analyzed over the three grazing seasons.

\subsection{Statistical Analysis}

For the analysis of forage yield, forage nutritive value, and mineral composition, the independent variables for analysis were fixed effects of the forage system (system 1 (CSP) or system 2 (CSP and WSA)), specific forage species (CSP species, BMRSS, or teff), month (June, July, August, September, and October) nested within the forage system, year $(2013,2014,2015)$ nested within the forage System, and interactions of month, system, and forage species and year, system, and forage species. Paddock was a random effect with date of harvest as repeated measures with the PROC MIXED procedure of SAS 9.4 [16]. The compound symmetry covariance structure was used because it resulted in the lowest Akaike's information criterion [17]. All treatment results were reported as least squares means, and significance was declared at $p<0.05$. Differences among treatments were tested using least squares means with the Tukey adjustment for multiple means comparison.

\section{Results}

\subsection{Forage Production by System}

The $p$-values from tests of significance for the statistical model forage nutritive value are in Table 1 . There was $38 \%$ greater seasonal forage yield $(p<0.05)$ in pasture system 2 compared with pasture system 1 (Table 2$)$. The average dry matter percentage did not differ $(p=0.44)$ between CSP and WSA grasses in the current study.

\subsection{Forage Nutritive Value across Grazing Season}

The least squares means for the seasonal forage nutritive value of CSP and WSA grasses (both BMRSS and teff combined) across the grazing season are shown in Table 2. Crude protein was greater 
$(p<0.01)$ in CSP grasses than in WSA grasses (Table 2). The NDF, ADF, and TTNDFD did not differ $(p>0.05)$ between CSP and WSA grasses. The calcium content of forages did not differ $(p=0.20)$ between CSP and WSA pastures, but phosphorus, potassium, and magnesium were all greater $(p<0.05)$ in WSA pasture than in CSP pasture.

Table 1. $p$-Values from tests of significance for forage nutritive value.

\begin{tabular}{ccccccc}
\hline & System & $\begin{array}{c}\text { Forage } \\
\text { Species }^{2}\end{array}$ & $\begin{array}{c}\text { Month } \times \\
\text { System }\end{array}$ & $\begin{array}{c}\text { Year } \times \\
\text { System }\end{array}$ & $\begin{array}{c}\text { Month } \times \text { System } \\
\times \text { Forage Species }\end{array}$ & $\begin{array}{c}\text { Year } \times \text { System } \times \\
\text { Forage Species }\end{array}$ \\
\hline Forage yield & 0.001 & 0.12 & 0.001 & 0.001 & 0.31 & 0.001 \\
Dry matter & 0.47 & 0.03 & 0.001 & 0.001 & 0.01 & 0.001 \\
Crude protein & 0.001 & 0.54 & 0.001 & 0.001 & 0.34 & 0.001 \\
NDF & 0.17 & 0.92 & 0.001 & 0.001 & 0.39 & 0.001 \\
ADF & 0.06 & 0.62 & 0.005 & 0.001 & 0.12 & 0.001 \\
TTNDFD & 0.84 & 0.62 & 0.001 & 0.001 & 0.19 & 0.14 \\
Calcium & 0.21 & 0.77 & 0.005 & 0.14 & 0.32 & 0.02 \\
Phosphorus & 0.03 & 0.05 & 0.001 & 0.02 & 0.99 & 0.001 \\
Potassium & 0.02 & 0.09 & 0.001 & 0.001 & 0.71 & 0.10 \\
Magnesium & 0.001 & 0.43 & 0.001 & 0.10 & 0.75 & 0.001 \\
$\mathrm{NE}_{\mathrm{L}}, \mathrm{MJ} / \mathrm{kg}$ & 0.02 & 0.83 & 0.64 & 0.001 & 0.74 & \\
\hline
\end{tabular}

${ }^{1}$ System 1 = cool-season perennial and system 2 = warm-season grasses; ${ }^{2}$ cool-season perennial, brown-midrib sorghum-sudangrass, teff; NDF = neutral detergent fiber; $\mathrm{ADF}=$ acid detergent fiber; TTNDFD = total tract NDF digestibility; $\mathrm{NE}_{\mathrm{L}}=$ net energy for lactation.

Table 2. Least squares means and standard errors for forage yield and nutritive value of cool-season perennial and cool-season-warm-season annual forage species.

\begin{tabular}{ccccc}
\hline & \multicolumn{2}{c}{ Cool-Season Perennial (System 1) } & \multicolumn{2}{c}{ Warm-Season Annual (System 2) } \\
\hline Variable & Mean & Standard Error & Mean & Standard Error \\
\hline Forage yield (kg DM/ha) & $2228^{\mathrm{b}}$ & 63 & $3088^{\mathrm{a}}$ & 241 \\
Dry matter, \% & $23.3^{\mathrm{a}}$ & 0.6 & 22.4 & 1.1 \\
Crude protein, \%DM & $23.0^{\mathrm{a}}$ & 0.5 & $18.0^{\mathrm{b}}$ & 0.9 \\
NDF, \%DM & 49.6 & 0.5 & 52.6 & 1.2 \\
ADF, \%DM & 32.2 & 0.4 & 33.7 & 0.7 \\
TTNDFD, \%NDF & 54.6 & 0.9 & 54.9 & 1.7 \\
Calcium, \%DM & 0.67 & 0.03 & 0.58 & 0.06 \\
Phosphorus, \%DM & $0.33^{\mathrm{b}}$ & 0.01 & $0.37^{\mathrm{a}}$ & 0.02 \\
Potassium, \%DM & $3.10^{\mathrm{b}}$ & 0.1 & $3.48^{\mathrm{a}}$ & 0.16 \\
Magnesium, \%DM & $0.23^{\mathrm{b}}$ & 0.01 & $0.31^{\mathrm{a}}$ & 0.02 \\
NEL, MJ/kg & $5.61^{\mathrm{b}}$ & 0.10 & $5.43^{\mathrm{a}}$ & 0.10 \\
\hline
\end{tabular}

a,b Means within a row with different superscripts are different at $p<0.05$. NDF = neutral detergent fiber; $\mathrm{ADF}=$ acid detergent fiber; TTNDFD = total tract NDF digestibility; $\mathrm{NE}_{\mathrm{L}}=$ net energy for lactation.

\subsection{Forage Yield and Nutritive Value by Year}

The forage yield of CSP grasses was greater $(p<0.01)$ in 2014 than 2015, but WSA grasses produced similar $(p=0.42)$ yields for both 2014 and 2015 (Table 3). Weather may have had an important role for the differences in forage production between years. Conditions in 2015 may have been challenging to CSP grasses because of the higher average temperature. The increased grazing pressure in 2015 at the start of the grazing season may have slowed the regrowth of these CSP grasses for the entire grazing season. Crude protein was greater $(p<0.05)$ in CSP grasses than WSA grasses in all years. The NDF and ADF were variable across the years but were similar $(p>0.05)$ for CSP and WSA grasses in 2015. The TTNDFD was different between CSP and WSA forages for $2013(p=0.04)$ and $2015(p=0.05)$ but was similar ( $p=0.31$ ) between forages for 2014. Calcium, phosphorus, potassium, and magnesium content all varied between years for CSP and WSA forages. Fluctuations of forage nutritive value for different years may be expected because weather conditions are different from year to year. 
Table 3. Least squares means and standard errors for forage yield and nutritive value characteristics of cool-season perennial and warm-season forages for years across the grazing season.

\begin{tabular}{|c|c|c|c|c|c|c|c|c|c|c|c|}
\hline & \multicolumn{6}{|c|}{ Cool-Season Perennial (System 1) } & \multicolumn{5}{|c|}{ Warm-Season Annual (System 2) } \\
\hline & June & July & August & September & October & & July & August & September & October & \\
\hline Variable & Mean & Mean & Mean & Mean & Mean & Mean SE & Mean & Mean & Mean & Mean & Mean SE \\
\hline Forage yield (kg DM/ ha) & $3168^{b}$ & $2757^{c}$ & $2024^{\mathrm{d}}$ & 1690 de & $1501^{\mathrm{e}}$ & 141 & $3766^{a}$ & $3014 \mathrm{bc}$ & $2962 \mathrm{abc}$ & 2609 abcde & 402 \\
\hline Dry matter, \% & $24.4 \mathrm{abc}$ & $21.1^{\mathrm{d}}$ & $25.0^{a b}$ & $21.9^{\mathrm{cd}}$ & 23.9 abcd & 1.0 & $15.9^{\mathrm{e}}$ & $23.8^{\mathrm{abcd}}$ & $21.9^{\mathrm{bcd}}$ & $28.0^{\mathrm{a}}$ & 1.8 \\
\hline Crude protein, \%DM & $20.7^{b}$ & $21.6^{\mathrm{b}}$ & $22.1^{\mathrm{b}}$ & $25.2^{\mathrm{a}}$ & $25.3^{\mathrm{a}}$ & 0.8 & $20.0^{b}$ & $17.2^{\mathrm{c}}$ & $17.0^{\mathrm{c}}$ & $17.9 \mathrm{bc}$ & 1.4 \\
\hline NDF, \%DM & $53.5^{\mathrm{a}}$ & $52.2^{\mathrm{ab}}$ & $51.6^{\mathrm{ab}}$ & $47.4^{\mathrm{c}}$ & $45.1^{\mathrm{c}}$ & 1.3 & $51.8^{\mathrm{ab}}$ & $55.5^{\mathrm{a}}$ & $54.4^{\mathrm{a}}$ & $46.4^{\mathrm{bc}}$ & 2.2 \\
\hline ADF, \%DM & $33.0^{b}$ & $33.2^{b}$ & $32.9^{b}$ & $31.4^{c}$ & $30.6^{c}$ & 0.7 & $32.8^{\mathrm{bc}}$ & $35.9^{a}$ & $34.3^{\mathrm{ab}}$ & $31.7^{b c}$ & 1.2 \\
\hline TTNDFD, \%NDF & $53.2^{b c}$ & $50.8^{c}$ & $50.3^{c}$ & $57.7^{\mathrm{a}}$ & $60.7^{\mathrm{a}}$ & 1.6 & $56.1^{\mathrm{ab}}$ & $50.5^{c}$ & $56.9^{a b}$ & $56.0^{\mathrm{abc}}$ & 2.5 \\
\hline Calcium, \%DM & $0.56^{\mathrm{d}}$ & $0.59^{\mathrm{cd}}$ & $0.71^{a b}$ & $0.76^{\mathrm{a}}$ & $0.71^{\mathrm{abc}}$ & 0.05 & $0.57^{\mathrm{bcd}}$ & $0.59^{\mathrm{abcd}}$ & $0.46^{\mathrm{d}}$ & 0.70 abcd & 0.1 \\
\hline Phosphorus, \%DM & $0.30^{b}$ & $0.30^{\mathrm{b}}$ & $0.30^{\mathrm{b}}$ & $0.37^{\mathrm{a}}$ & $0.36^{\mathrm{a}}$ & 0.02 & $0.37^{\mathrm{a}}$ & $0.34^{\mathrm{ab}}$ & $0.37^{\mathrm{a}}$ & $0.39^{\mathrm{a}}$ & 0.03 \\
\hline Potassium, \%DM & $2.74^{\mathrm{d}}$ & $2.89 \mathrm{~cd}$ & $2.97^{\mathrm{cd}}$ & $3.43^{b}$ & $3.47^{\mathrm{ab}}$ & 0.13 & $3.85^{\mathrm{a}}$ & $3.31^{b c}$ & $3.28 \mathrm{bc}$ & $3.49 \mathrm{abc}$ & 0.2 \\
\hline Magnesium, \%DM & $0.18^{\mathrm{e}}$ & 0.20 de & $0.25^{c}$ & $0.26^{b c}$ & $0.24^{\mathrm{cd}}$ & 0.01 & $0.28^{a b c}$ & $0.31^{\mathrm{ab}}$ & $0.31^{\mathrm{ab}}$ & $0.35^{\mathrm{a}}$ & 0.03 \\
\hline $\mathrm{NE}_{\mathrm{L}}, \mathrm{MJ} / \mathrm{kg}$ & $5.52 \mathrm{abc}$ & $5.52 \mathrm{abc}$ & $5.61^{\mathrm{ab}}$ & $5.61 \mathrm{abc}$ & $5.70^{\mathrm{a}}$ & 0.10 & $5.43^{b c}$ & $5.33^{c}$ & $5.43^{a b c}$ & $5.33^{a b c}$ & 0.10 \\
\hline
\end{tabular}

$\mathrm{a}, \mathrm{b}, \mathrm{c}, \mathrm{d}$ Means within a row with different superscripts are different at $p<0.05$. BMRSS = brown-midrib sorghum-sudangrass; DM = dry matter, NDF $=$ neutral detergent fiber; $\mathrm{ADF}=\mathrm{acid}$ detergent fiber; TTNDFD = total tract NDF digestibility; $\mathrm{NE}_{\mathrm{L}}=$ net energy for lactation. 


\subsection{Forage Nutritive Value for CSP and WSA by Month}

The CSP forage was the only system with forage available in June due to the growth patterns of the different grass species (Table 4). Both CSP and WSA forages experienced a decline in forage yield as the grazing season progressed from spring to fall. The WSA forage had greater $(p<0.05)$ forage yield than the CSP forage for July, August, and September, which can be attributed to higher temperatures of the summer months. For CP, the WSA forage was similar $(p=0.14)$ to the CSP forage in July, although for the remainder of the grazing season, the WSA forage had lower $(p<0.01) \mathrm{CP}$ than the CSP forage. The NDF and ADF of the CSP and WSA forages were similar $(p>0.05)$ in July, but the ADF of the CSP was lower $(p<0.01)$ than that of the WSA forage in August, and the NDF and ADF of the CSP forage were both lower $(p<0.05)$ than those of the WSA forage in September. The TTNDFD of the forages was greater $(p<0.01)$ for the WSA forage than the CSP forage in July, most likely due to the sooner maturity of the WSA at this time of the grazing season. The mineral content of the forages was high during the spring, decreased during the summer, and increased during the fall. The increase of mineral content in the fall offset the decrease during the summer and potassium increase to a higher level during the fall.

Table 4. Least squares means and standard errors for forage yield and nutritive value characteristics of cool-season perennial and warm-season forages for months across the grazing season.

\begin{tabular}{|c|c|c|c|c|c|c|c|c|}
\hline & \multicolumn{4}{|c|}{ Cool-Season Perennial (System 1) } & \multicolumn{4}{|c|}{ Warm-Season Annual (System 2) } \\
\hline & 2013 & 2014 & 2015 & & 2013 & 2014 & 2015 & \\
\hline Variable & Mean & Mean & Mean & Mean SE & Mean & Mean & Mean & Mean SE \\
\hline Forage yield (kg DM/ha) & & $2440^{b}$ & $2016^{c}$ & 89 & & $2950^{a}$ & $3226^{a}$ & 288 \\
\hline Dry matter, $\%$ & $25.9^{\mathrm{a}}$ & $22.5^{b}$ & $21.4^{\mathrm{b}}$ & 0.9 & $27.0^{\mathrm{a}}$ & $21.2^{b}$ & $19.0^{\mathrm{b}}$ & 1.6 \\
\hline Crude protein, \%DM & $20.9^{c}$ & $23.2^{b}$ & $24.8^{\mathrm{a}}$ & 0.7 & $14.6^{\mathrm{d}}$ & $19.0^{c}$ & $20.5^{b c}$ & 1.3 \\
\hline NDF, \%DM & $51.6^{\mathrm{bc}}$ & $49.8^{\mathrm{cd}}$ & $48.4^{\mathrm{d}}$ & 1.1 & $56.9^{\mathrm{a}}$ & $53.8^{\mathrm{ab}}$ & $45.4^{\mathrm{d}}$ & 2.0 \\
\hline $\mathrm{ADF}, \% \mathrm{DM}$ & $34.7^{b}$ & $30.7^{\mathrm{d}}$ & $31.3^{\mathrm{cd}}$ & 0.6 & $37.7^{\mathrm{a}}$ & $32.7^{\mathrm{c}}$ & $30.5^{\mathrm{cd}}$ & 1.1 \\
\hline TTNDFD, \%NDF & $63.8^{a}$ & $48.0^{\mathrm{d}}$ & $51.9^{c}$ & 1.3 & $59.3^{b}$ & $46.3^{\mathrm{d}}$ & $59.1^{\mathrm{ab}}$ & 2.3 \\
\hline Calcium, \%DM & $0.74^{\mathrm{a}}$ & $0.60^{b}$ & $0.66^{\mathrm{ab}}$ & 0.04 & $0.58^{\mathrm{ab}}$ & $0.53^{b}$ & $0.64^{\mathrm{ab}}$ & 0.09 \\
\hline Phosphorus, \%DM & $0.34^{\mathrm{a}}$ & $0.33^{\mathrm{a}}$ & $0.30^{\mathrm{b}}$ & 0.01 & $0.35^{\mathrm{a}}$ & $0.35^{\mathrm{a}}$ & $0.39^{\mathrm{a}}$ & 0.03 \\
\hline Potassium, \%DM & $3.36^{b}$ & $2.92^{\mathrm{cd}}$ & $3.03^{c}$ & 0.12 & $3.05^{b c d}$ & $2.68^{d}$ & $4.71^{\mathrm{a}}$ & 0.22 \\
\hline Magnesium, \%DM & $0.24^{\mathrm{cd}}$ & $0.22^{\mathrm{d}}$ & $0.22^{d}$ & 0.01 & $0.30^{\mathrm{ab}}$ & $0.27^{b c}$ & $0.36^{\mathrm{a}}$ & 0.03 \\
\hline $\mathrm{NE}_{\mathrm{L}}, \mathrm{MJ} / \mathrm{kg}$ & $5.43^{b}$ & $5.61^{b}$ & $5.79^{a}$ & 0.10 & $5.06^{c}$ & $5.61^{\mathrm{ab}}$ & $5.52^{a b}$ & 0.10 \\
\hline
\end{tabular}

$\mathrm{a}, \mathrm{b}, \mathrm{c}, \mathrm{d}$ Means within a row with different superscripts are different at $p<0.05$. BMRSS $=$ brown-midrib sorghum-sudangrass; $\mathrm{DM}=$ dry matter; $\mathrm{NDF}=$ neutral detergent fiber; $\mathrm{ADF}=$ acid detergent fiber; $\mathrm{TTNDFD}=$ total tract $\mathrm{NDF}$ digestibility; $\mathrm{NE}_{\mathrm{L}}=$ Net energy for lactation.

\subsection{Forage Nutritive Value and Yield for CSP, BMR Sorghum-Sudangrass, and Teff}

Least squares means and standard errors for average forage yield and nutritive value for CSP grasses, BMRSS, and teff are presented in Table 5. The forage yield of BMRSS was greater $(p<0.01)$ than that of CSP grasses, while teff was intermediate and similar to CSP grasses $(p>0.05)$ and BMRSS $(p>0.05)$. Dry matter was lower $(p<0.05)$ for BMRSS than CSP grasses and teff (Table 6). Crude protein was greater $(p<0.01)$ for CSP grasses than BMRSS and teff. The forage NDF, ADF, and TTNDFD were similar $(p>0.05)$ for CSP grasses, BMRSS, and teff.

Calcium did not differ $(p>0.05)$ among the forage species. Phosphorus was greater $(p<0.05)$ for teff than CSP grasses and BMRSS. Potassium was greater $(p=0.02)$ for teff than cool-season pasture forage, but the potassium content of BMRSS was similar $(p>0.05)$ for both CSP grasses and teff. Magnesium was similar $(p=0.43)$ for BMRSS and teff, and BMRSS and teff had greater $(p<0.01)$ magnesium values than CSP grasses. 
Table 5. Least squares means and standard errors for forage yield and nutritive value characteristics for cool-season perennial, BMR sorghum-sudangrass (BMRSS), and teff across the grazing season.

\begin{tabular}{ccccccc}
\hline & \multicolumn{2}{c}{ Cool-Season Perennial } & \multicolumn{2}{c}{ BMRSS } & \multicolumn{2}{c}{ Teff } \\
\hline Variable & Mean & Standard Error & Mean & Standard Error & Mean & Standard Error \\
\hline Forage yield (kg DM/ha) & $2228^{\mathrm{b}}$ & 63 & $3455^{\mathrm{a}}$ & 306 & $2722^{\mathrm{ab}}$ & 365 \\
Dry matter, \% & $23.3^{\mathrm{a}}$ & 0.6 & $20.2^{\mathrm{b}}$ & 1.1 & $24.6^{\mathrm{a}}$ & 1.7 \\
Crude protein, \%DM & $23.0^{\mathrm{a}}$ & 0.5 & $18.5^{\mathrm{b}}$ & 0.9 & $17.5^{\mathrm{b}}$ & 1.4 \\
NDF, \%DM & 50.0 & 0.9 & 51.9 & 1.5 & 52.1 & 2.2 \\
ADF, \% DM & 32.2 & 0.4 & 33.3 & 0.8 & 34.0 & 1.2 \\
TTNDFD, \%NDF & 54.6 & 0.9 & 54.2 & 1.6 & 55.6 & 2.6 \\
Calcium, \%DM & 0.67 & 0.03 & 0.60 & 0.07 & 0.56 & 0.10 \\
Phosphorus, \% DM & $0.33^{\mathrm{b}}$ & 0.01 & $0.34^{\mathrm{b}}$ & 0.02 & $0.40^{\mathrm{a}}$ & 0.03 \\
Potassium, \% DM & $3.10^{\mathrm{b}}$ & 0.1 & $3.25^{\mathrm{ab}}$ & 0.17 & $3.71^{\mathrm{a}}$ & 0.25 \\
Magnesium, \% DM & $0.23^{\mathrm{b}}$ & 0.01 & $0.33^{\mathrm{a}}$ & 0.02 & $0.30^{\mathrm{a}}$ & 0.03 \\
NE $_{\mathrm{L}}, \mathrm{MJ} / \mathrm{kg}$ & $5.61^{\mathrm{a}}$ & 0.10 & $5.43^{\mathrm{b}}$ & 0.10 & $5.43^{\mathrm{ab}}$ & 0.10 \\
\hline
\end{tabular}

a,b Means within a row with different superscripts are different at $p<0.05$. BMRSS $=$ brown-midrib sorghum-sudangrass; $\mathrm{DM}=$ dry matter; $\mathrm{NDF}=$ neutral detergent fiber; $\mathrm{ADF}=$ acid detergent fiber; $\mathrm{TTNDFD}=$ total tract $\mathrm{NDF}$ digestibility; $\mathrm{NE}_{\mathrm{L}}=$ net energy for lactation.

Table 6. Weather data for 2013-2015 measured at the West Central Research and Outreach Center, Morris, MN, weather station.

\begin{tabular}{cccccc}
\hline & & \multicolumn{3}{c}{ Temperature $\left({ }^{\circ} \mathbf{C}\right)$} & Rainfall (mm) \\
\hline Year & Month & High & Low & Average & Monthly Total \\
\hline \multirow{2}{*}{013} & May & 18.3 & 6.1 & 12.2 & 61 \\
& June & 23.9 & 13.3 & 18.3 & 237 \\
& July & 27.2 & 15.6 & 21.7 & 65 \\
& August & 26.7 & 13.3 & 20.0 & 27 \\
& September & 23.9 & 10.6 & 17.2 & 88 \\
& October & 12.2 & 2.2 & 7.2 & 92 \\
\hline \multirow{2}{*}{2014} & May & 17.2 & 6.7 & 12.8 & 75 \\
& June & 24.4 & 13.9 & 19.4 & 208 \\
& July & 25.6 & 13.9 & 20.0 & 46 \\
& August & 25.0 & 15.0 & 20.0 & 146 \\
& September & 21.7 & 9.4 & 15.6 & 36 \\
& October & 15.0 & 1.7 & 8.3 & 13 \\
\hline \multirow{2}{*}{2015} & May & 18.9 & 7.2 & 13.3 & 197 \\
& June & 25.6 & 13.9 & 20.0 & 47 \\
& July & 27.2 & 16.1 & 21.7 & 93 \\
& August & 25.6 & 13.3 & 19.4 & 160 \\
& September & 25.0 & 12.2 & 18.9 & 34 \\
& October & 15.6 & 3.3 & 9.4 & 40 \\
\hline
\end{tabular}

\section{Discussion}

Weather data were recorded daily at the University of Minnesota West Central Research and Outreach Center weather station in Morris, MN. Monthly high, low, and average temperature and total monthly precipitation for the six months of the grazing season are shown in Table 6.

The highest precipitation across the three years was in June 2013, June 2014, August 2014, May 2015, and August 2015 (Table 4). The lowest total precipitation was in 2014. The driest months were August 2013, September 2014, October 2014, and September 2015. Typically, July and August were the months with the highest temperatures and humidity in all three years. The highest average temperature during the grazing season was 2015. The high temperatures and low precipitation in July and August may have challenged the CSP pastures. The variable weather conditions among the three years of the study provided the opportunity to evaluate the productivity of the pastures under different growing 
conditions. Weather may have had an important role for the differences in forage production between years. Conditions in 2015 may have been challenging to CSP grasses because of the higher average temperature (Table 1). The increased grazing pressure in 2015 at the start of the grazing season may have slowed the regrowth of CSP grasses for the entire grazing season. Fluctuations of forage nutritive value for different years may be expected because weather conditions are different from year to year.

Although pastures planted with WSA may not be in use for the entire grazing period, they provide additional forage when drought conditions persist or when CSP grasses become dormant [4]. For the current study, incorporating WSA grasses into a grazing system may extend the grazing season and assist organic dairy farmers to comply with the organic pasture rule in the USA. Furthermore, farmers may be able to increase stocking density with the additional forage produced from WSA grasses.

These results are consistent with those of previous research that showed CSP grasses had higher CP than WSA grasses in the Midwest and Pacific Northwest, USA $[4,5,7,11,18]$. The average CP for WSA grasses in this study was $18 \%$, which met the recommended $16 \%$ to $18 \% \mathrm{CP}$ in lactating dairy cow diets [19]. However, in Wisconsin Colmenero and Broderick [20] determined that a $16.5 \% \mathrm{CP}$ was optimal for maximizing milk production while limiting the amount of $\mathrm{N}$ excreted by dairy cows. The $\mathrm{CP}$ of forages is an important measure of forage nutritive value because milk $\mathrm{N}$ efficiency decreases as dietary $\mathrm{CP}$ increases [21]. Although the $\mathrm{CP}$ values of WSA grasses from the current study were higher than the optimal CP level, the lower CP observed in WSA grasses compared with that in CSP grasses may be beneficial for cows because they may not expend as much energy on excreting excess nitrogen [22]. Quite possibly, the forage nutritive value of CSP forage in the current study was related to the high proportion of grasses compared with legumes in the grazing sward. The percentage of grasses to legumes in a pasture may have different forage nutritive values and, therefore, different effects on grazing livestock. The higher percentage of grasses compared with legumes in the current study may have had a greater effect of higher CP and NDF than what producers may observe on their farm depending on the species mixture used in pastures. A diverse mixture of grasses and legumes in pasture may be effective in optimizing the forage nutritive value of the pasture. While the current study found similar NDF and ADF values for CSP and WSA grasses, prior studies reported greater NDF and ADF values for WSA grasses than CSP grasses [4,5,23,24]. Moore et al. [4] reported greater NDF and ADF from mainly bluestem and switchgrass pastures possibly because forage was not in an ideal vegetative state, which decreased the forage nutritive value. Differences between the values observed in the current study and those in the literature may be attributed to variabilities due to species and growing conditions across geographic areas [5]. Differences for CSP and WSA grasses may also be explained by the fact that cell wall contents are usually greater for warm-season grasses [4], which results in greater fiber concentration in forage. Grazing cows may experience changes in forages throughout the grazing season due to weather, the increasing maturity of CSP and WSA grasses, and changes in season in regions in the USA.

One limitation of WSA grasses in a grazing system is that for the early part of the season, those pastures are unavailable to grazing animals [5]. These results convey the potential for WSA grasses to be used for dairy grazing systems to compensate for pasture forage yield when CSP grasses experience decreased growth. Similarly, in another study, WSA grasses produced greater forage yield in August than CSP grasses [7]. The CP for WSA grasses in the current study was similar to that in the study of Tracey et al. [7], but the tall fescue, bluegrass, orchardgrass, and white clover for CSP grasses were much lower than those in the current study. The results of monthly CP values of WSA grasses in the current study point to a promising future of using WSA grasses in grazing systems in the Midwest. The similar CP of CSP and WSA grasses in July indicates that WSA grasses had similar forage nutritive value to CSP grasses when they would be most desirable for a grazing system. Similarly, Jones and Tracy [25] found that the patterns of mineral content in CSP grasses followed a pattern of high spring content, low summer content, and high fall content following grass maturation across the growing season. An annual cool-season mix planted in April may be a solution for the month of June in which forage availability is low and could warrant possible future research. 
Previous studies comparing yields of sorghum-sudangrass and teff in simulated mechanical harvesting systems have shown inconsistent differences in values $[11,26]$. However, these results are difficult to compare with the results of a grazing study where livestock impact occurs. Studies that have reported yields of sorghum-sudangrass and other WSA grasses for a grazing system used different heights of sample harvest and different grazing schedules [4,7], which made it difficult to compare yields within the grazing systems in the current study. The CP of both BMRSS and teff averaged 18\% and met the recommended $16 \%$ to $18 \%$ dietary protein requirements of a lactating dairy cow [19]. The NDF and ADF of teff in the current study are within the range found in Oregon and Washington and the range found in New York $[27,28]$. Each of the forage species in this study had greater than $50 \%$ TTNDFD, which is the goal for good nutritive value grass forages [29].

Based on the results of the current study, teff may be an excellent source of nutrition for grazing dairy cattle; however, when pooled with BMRSS, teff may lose importance and value. Teff has the potential to be a highly nutritive forage for dairy cattle if continually harvested at an early stage of maturity. Teff had similar CP, TTNDFD, and net energy for lactation compared with BMRSS in the current study, and provided the understanding that teff could be incorporated in a pasture and forage production system. However, irrigation may be needed to provide optimal growth of teff grass in pastures, and during the autumn, teff may not be able to withstand cold or freezing temperatures. Furthermore, teff growth would likely be minimal during the late summer or early autumn in the Upper Midwest, USA, because optimal teff growth occurs at around 15 to $21^{\circ} \mathrm{C}$ [30]. Additional research needs to be conducted on increasing yield, teff yields and nutritive value in various conditions, and the effects on production of feeding teff to dairy cattle.

Normally, grasses with high potassium are monitored carefully when grazed by late lactation and dry cows, but organic producers are less likely than conventional producers to limit potassium levels in dry cow diets [31]. Further research may be needed to determine how management of grasses high in potassium affects cows in an organic grazing system.

This study demonstrated that WSA grasses can be successfully grown and grazed in the Upper Midwest, but farmers should expect yearly and monthly variation. This study found varying forage nutritive values for WSA and CSP grasses, so dairy farmers should not worry that adding WSA grasses to CSP pastures will sacrifice the forage nutritive value. High nutritive value CSP pastures often have high protein content that may exceed dairy cattle nutrition requirements [23,32]. One of the most important aspects to keep dietary protein balanced in a dairy diet is to ensure the cows also have adequate energy in their diet. Grasses alone may not meet National Research Council (NRC) energy requirements for cows, especially in order to keep energy in balance with the high protein available in grasses [32]. One solution to this situation is to provide cows with grain or other concentrates as an energy source.

Grazing cows experience changes in diets throughout the grazing season due to weather and increased maturity of CSP grasses. Cows in a grazing system may have disruptions to their diets because of grazing monoculture grasses and then switching to grazing a different type of monoculture grass [33]. Results from an in vitro continuous culture study reported changes in ruminal fermentation among CSP and WSA grasses, and BMRSS and teff grass had similar digestibility values when compared with CSP grasses. Overall, fermentation of WSA grasses was similar to that of CSP grasses [33].

One disadvantage of WSA grasses in a grazing system is that they may not become available until the middle of the grazing season. However, a system that incorporates WSA grasses may yield more forage across the whole grazing season. Therefore, farmers should determine whether they will have adequate CSP grasses at the beginning of the grazing season to successfully graze their animals when WSA grasses may not be available. Labor is needed to plant WSA grasses each year to manage more rotations of animals and to monitor BMRSS to prevent prussic acid and nitrate poisoning. For grazing livestock, nitrate toxicity may be an issue with BMRSS because concentrations of nitrates are increased with plants that are grazed at an immature stage or after freezing temperatures [34]. Therefore, farmers manage BMRSS carefully so as to prevent associated challenges with grazing livestock. 
Grazing seasons may be short in the Upper Midwestern regions of the USA because of the chance of early freezing temperatures that may occur. Producing enough forage for grazing cattle is an obstacle shared by livestock producers in similar climates. Dairy producers should increase forage production throughout the grazing season, and irrigation on the farm may be an option to offset weather and possible drought conditions. Increased precipitation during the grazing season may lead to delays in grazing pastures, which may lead to forages that are mature by grazing time. Temperature affects how forages mature, increased extreme weather events may lower forage yields, warmer temperatures lower the forage quality of CSP grasses, and cooler temperatures allow forages to remain in a vegetative state and, therefore, provide for a higher nutritive value of forages [35].

Farmers should plant both CSP and WSA grasses in pastures to increase forage productivity across a grazing season and to reduce the risks related to unknown weather conditions and the effects of climate change. Grazing producers would need to make decisions regarding the interaction of forage nutritive value and forage yield to maintain profitability of their operation. Increased forage yield may decrease forage quality for CSP grasses. Therefore, WSA grasses may be planted to assist in keeping CSP grasses in a more vegetative state to increase the forage nutritive value. Grazing livestock producers should determine the optimum species mix and proportion of CSP grasses for their specific environmental conditions to increase the forage production of their pasture.

Economic analysis of WSA grasses in pasture systems in the Midwest is needed. Although there may be a higher cost for seed and additional labor each year, there may be a greater benefit to including WSA grasses in a grazing rotation. There is also a need for future research to estimate the optimal amount and different species of WSA grasses to be incorporated in a grazing system.

\section{Conclusions}

This study determined that BMRSS and teff may provide favorable forage production with similar nutritional nutritive value to that of CSP grasses. Given their forage nutritive value, warm-season grasses may be beneficial forages to include in pastures for dairy grazing operations in the Upper Midwest. In certain months, WSA grasses had higher yield and higher forage nutritive value than CSP grasses, indicating the potential for WSA pastures to augment the grazing season without sacrificing nutritive value.

Author Contributions: Conceptualization, B.J.H., R.M., S.L.W., C.S.; methodology, B.J.H., K.E.R.; software, B.J.H., K.E.R.; validation, B.J.H., K.E.R.; formal analysis, B.J.H., K.E.R.; investigation, B.J.H., K.E.R.; resources, B.J.H.; data curation, B.J.H., K.E.R.; writing-original draft preparation, K.E.R.; writing-review and editing, B.J.H., K.E.R., R.M., C.S., S.L.W.; supervision, B.J.H.; project administration, B.J.H.; funding acquisition, B.J.H., C.S., R.M., S.L.W. All authors have read and agreed to the published version of the manuscript.

Funding: This work is supported by the Organic Agriculture Research and Extension Initiative (grant no. 2012-51300-20015/project accession no. 0230589) from the USDA National Institute of Food and Agriculture.

Acknowledgments: The authors of this paper acknowledge Darin Huot and the workers at the West Central Research and Outreach Center who helped with grazing management and forage clippings, which made this study possible.

Conflicts of Interest: The authors declare no conflict of interest. The funders had no role in the design of the study; in the collection, analyses, or interpretation of data; in the writing of the manuscript; or in the decision to publish the results.

\section{References}

1. White, S.L.; Benson, G.A.; Washburn, S.P.; Green, J.T. Milk production and economic measures in confinement or pasture systems using seasonally calved Holstein and Jersey cows. J. Dairy Sci. 2002, 85, 95-104. [CrossRef] [PubMed]

2. Maher, J.; Stakelum, G.; Rath, M. Effect of daily herbage allowance on the performance of spring-calving dairy cows. Ir. J. Agric. Food Res. 2003, 42, 229-241.

3. Electronic Code of Federal Regulations. Available online: https://www.ecfr.gov/ (accessed on 20 September 2019). 
4. Moore, K.J.; White, T.A.; Hintz, R.L.; Patrick, P.K.; Brummer, E.C. Sequential grazing of cool- and warm-season pastures. Agron. J. 2004, 96, 1103-1111. [CrossRef]

5. Hudson, D.J.; Leep, R.H.; Dietz, T.S.; Ragavendran, A.; Kravchenko, A. Integrated warm- and cool-season grass and legume pastures: I. Seasonal forage dynamics. Agron. J. 2010, 102, 303-309. [CrossRef]

6. DeBoer, M.L.; Sheaffer, C.C.; Grev, A.M.; Catalano, D.N.; Wells, M.S.; Hathaway, M.R.; Martinson, K.L. Yield, nutritive value, and preference of annual warm-season grasses grazed by horses. Agron. J. 2017, 109, 2136-2148. [CrossRef]

7. Tracy, B.F.; Maughan, M.; Post, N.; Faulkner, D.B. Integrating annual and perennial warm-season grasses in a temperate grazing system. Crop Sci. 2010, 50, 2171-2177. [CrossRef]

8. Hafla, A.N.; MacAdam, J.W.; Soder, K.J. Sustainability of US organic beef and dairy production systems: Soil, plant and cattle interactions. Sustainability 2013, 5, 3009-3034. [CrossRef]

9. McCartney, D.; Fraser, J.; Ohama, A. Potential of warm-season annual forages and brassica crops for grazing: A Canadian Review. Can. J. Anim. Sci. 2009, 89, 431-440. [CrossRef]

10. Griggs, T.C.; Drake, D.R.; Parkinson, S.C. Production and quality of warm-season annual forage grasses. In Proceedings of the Idaho Alfalfa and Forage Conference, Twin Falls, ID, USA, 26-27 February 2008.

11. Noland, R.L.; Sheaffer, C.C.; Coulter, J.A.; Becker, R.L.; Wells, M.S. Yield, nutritive value, and profitability of firect-seeded annual forages following spring-terminated alfalfa. Agron. J. 2017, 109, 2738-2748. [CrossRef]

12. Dubeux, J.C.B.; Sollenberger, L.E.; Mathews, B.W.; Scholberg, J.M.; Santos, H.Q. Nutrient cycling in warm-climate grasslands. Crop Sci. 2007, 47, 915-928. [CrossRef]

13. Fisher, D.S. Defining the experimental unit in grazing trials. J Anim. Sci 2000, 77, 1-5. [CrossRef]

14. Lopes, F.; Ruh, K.; Combs, D.K. Validation of an approach to predict total-tract fiber digestibility using a standardized in vitro technique for different diets fed to high-producing dairy cows. J. Dairy Sci. 2015, 98, 2596-2602. [CrossRef] [PubMed]

15. Shaver, R.D. Corn silage evaluation: The MILK2006 update. In Proceedings of the 41st Pacific Northwest Animal Nutrition Conference, Vancouver, BC, Canada, 18-19 January 2016; pp. 67-76. Available online: https://fyi.extension.wisc.edu/forage/evaluating-corn-silage-quality-for-dairy-cattle/ (accessed on 20 October 2020).

16. Statistical Analysis Systems (SAS) Institute. SAS User's Guide; SAS Institute: Cary, NC, USA, 2016.

17. Littell, R.C.; Henry, P.R.; Ammerman, C.B. Statistical analysis of repeated measures data using SAS procedures. J. Anim. Sci. 1998, 76, 1216-1231. [CrossRef] [PubMed]

18. Bohnert, D.W.; DelCurto, T.; Clark, A.A.; Merrill, M.L.; Falck, S.J.; Harmon, D.L. Protein supplementation of ruminants consuming low-quality cool- or warm-season forage: Differences in intake and digestibility. J. Anim. Sci. 2011, 89, 3707-3717. [CrossRef]

19. Nutrient Requirements of Dairy Cattle (NRC). Available online: https://www.nap.edu/catalog/9825/nutrientrequirements-of-dairy-cattle-seventh-revised-edition-2001 (accessed on 20 October 2020).

20. Colmenero, J.J.O.; Broderick, G.A. Effect of dietary crude protein concentration on milk production and nitrogen utilization in lactating dairy cows. J. Dairy Sci. 2006, 89, 1704-1712. [CrossRef] [PubMed]

21. Huhtanen, P.; Nousiainen, J.I.; Rinne, M.; Kytölä, K.; Khalili, H. Utilization and partition of dietary nitrogen in dairy cows fed grass silage-based diets. J. Dairy Sci. 2008, 91, 3589-3599. [CrossRef]

22. Milano, G.D.; Hotston-Moore, A.; Lobley, G.E. Influence of hepatic ammonia removal on ureagenesis, amino acid utilization and energy metabolism in the ovine liver. Br. J. Nutr. 2000, 83, 307-315. [CrossRef]

23. Soder, K.J.; Sanderson, M.A.; Stack, J.L.; Muller, L.D. Intake and performance of lactating cows grazing diverse forage mixtures. J. Dairy Sci. 2006, 89, 2158-2167. [CrossRef]

24. Bainbridge, M.L.; Egolf, E.; Barlow, J.W.; Alvez, J.P.; Roman, J.; Kraft, J. Milk from cows grazing on cool-season pastures provides an enhanced profile of bioactive fatty acids compared to those grazed on a monoculture of pearl millet. Food Chem. 2017, 217, 750-755. [CrossRef]

25. Jones, G.B.; Tracy, B.F. Evaluating seasonal variation in mineral concentration of cool-season pasture herbage. Grass Forage Sci. 2015, 70, 94-101. [CrossRef]

26. Venuto, B.; Kindiger, B. Forage and biomass feedstock production from hybrid forage sorghum and sorghum-sudangrass hybrids. Grassl. Sci. 2008, 54, 189-196. [CrossRef]

27. Hunter, M.; Ketterings, Q.M.; Cherney, J.H.; Barney, P.; Kilcer, T.; Godwin, G. Nitrogen needs of teff managed as forage crop in New York. Forage Grazinglands 2009, 7, 1-9. [CrossRef] 
28. Norberg, S.; Roseberg, R.J.; Charlton, B.A.; Shock, C.C. Teff, A New Warm Season Annual Grass for Oregon. Oregon State University Extension Service. EM 8970-E. 2009. Available online: https://catalog.extension. oregonstate.edu/sites/catalog/files/project/pdf/em8970.pdf (accessed on 21 October 2020).

29. Goeser, J. Total Tract NDF Digestibility (TTNDFD) Guidelines, Rock River Laboratories. Available online: http://rockriverlab.com/file_open.php?id=119 (accessed on 1 November 2019).

30. Berretto, R.; Buenavista, R.M.; Rivera, J.L.; Wang, S.; Vara Prasad, P.V.; Siliveru, K. Teff (Eragrostis tef) processing, utilization, and future opportunities: A review. Inst. Food Sci. Tech. 2020. [CrossRef]

31. Sorge, U.S.; Moon, R.; Wolff, L.J.; Michels, L.; Schroth, S.; Kelton, D.F.; Heins, B. Management practices on organic and conventional dairy herds in Minnesota. J. Dairy Sci. 2016, 99, 3183-3192. [CrossRef] [PubMed]

32. Peyraud, J.L.; Delagarde, R. Managing variations in dairy cow nutrient supply under grazing. Animal 2013, 7, 57-67. [CrossRef] [PubMed]

33. Ruh, K.E.; Heins, B.J.; Salfer, I.J.; Gardner, R.G.; Stern, M.D. Comparison of warm season and cool season forages for dairy grazing systems in continuous culture. Trans. Anim. Sci. 2018, 2, 125-134. [CrossRef]

34. Bleier, J.S.; Coblentz, W.K.; Kalscheur, K.F.; Panke-Buisse, K.; Brink, G.E. Evaluation of warm season annual forages for forage yield and quality in the north-central United States. Trans. Anim. Sci. 2020, 4, 1-20. [CrossRef]

35. Tubiello, F.N.; Soussana, J.-F.; Howden, S.M. Crop and pasture response to climate change. Proc. Natl. Acad. Sci. USA 2007, 104, 19686-19690. [CrossRef]

Publisher's Note: MDPI stays neutral with regard to jurisdictional claims in published maps and institutional affiliations. 